CRYSTALLOGRAPHIC COMMUNICATIONS

ISSN 2056-9890

Received 5 January 2021

Accepted 19 January 2021

Edited by M. Zeller, Purdue University, USA

Keywords: crystal structure; cadmium(II)

complex; hydrazone derivatives.

CCDC reference: 2051612

Supporting information: this article has supporting information at journals.iucr.org/e

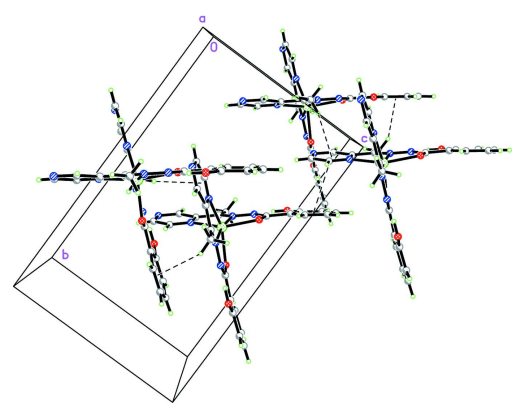

OPEN Ә ACCESS

\section{Crystal structure of bis\{2-hydroxy- $N^{\prime}-[1-(p y r a z i n-2-$ yl)ethylidene]benzohydrazidato\}cadmium(II)}

\author{
Ping Yang, Xiao-Bao Xie* and Qing-Shan Shi
}

Guangdong Provincial Key Laboratory of Microbial Culture Collection and Application, State Key Laboratory of Applied Microbiology Southern China, Guangdong Institute of Microbiology, Guangdong Academy of Sciences, Guangzhou 510070, People's Republic of China. *Correspondence e-mail: 191723030@qq.com

In the title complex molecule, $\left[\mathrm{Cd}\left(\mathrm{C}_{13} \mathrm{H}_{11} \mathrm{~N}_{4} \mathrm{O}_{2}\right)_{2}\right]$, the $\mathrm{Cd}$ atom is coordinated in a distorted octahedral geometry by two tridentate ligands synthesized from 2-hydroxybenzohydrazide and 1-(pyrazin-2-yl)ethan-1-one. The molecule has twofold crystallographic symmetry and is isomorphous to its $\mathrm{Mn}, \mathrm{Co}, \mathrm{Ni}, \mathrm{Cu}$ and Zn counterparts.

\section{Chemical context}

Aroylhydrazones are competent ligands for various functional coordination compounds. They have the ability of polydentate coordination and are often used as building units of polynuclear magnetic compounds (Huang et al., 2016; Zhang et al., 2010). Aroylhydrazones can exhibit keto-enol tautomerism, and the uncomplexed aroylhydrazone ligand is commonly found in its keto form (Kalinowski et al., 2008; Tai \& Feng, 2008). Metal complexes of deprotonated aroylhydrazones have been used in various catalytic and biological applications (Sutradhar et al., 2013; Yang et al., 2019; Yang, Chen et al., 2020). Aroylhydrazones synthesized from arylhydrazides and aromatic aldehydes/ketones with a nitrogen or oxygen atom in the ortho position can coordinate to metals in a tridentate chelating mode (Cindrić et al., 2017; Patel et al., 2018; You et $a l ., 2018$ ), and they have been used as probes and chemosensors for various metal ions. For example, the aroylhydrazone ligand containing a 4-(dimethylamino)phenylpropenyl or benzamide substituent specifically senses $\mathrm{Al}^{3+}$, $\mathrm{Cd}^{2+}$ (Kar et al., 2015) and $\mathrm{Ni}^{2+}$ ions (Manna et al., 2019) through significant changes in their absorption and emission spectroscopic behaviour after complexation with the metal ions. Here, we study the coordination attributes of an aroylhydrazone with cadmium.

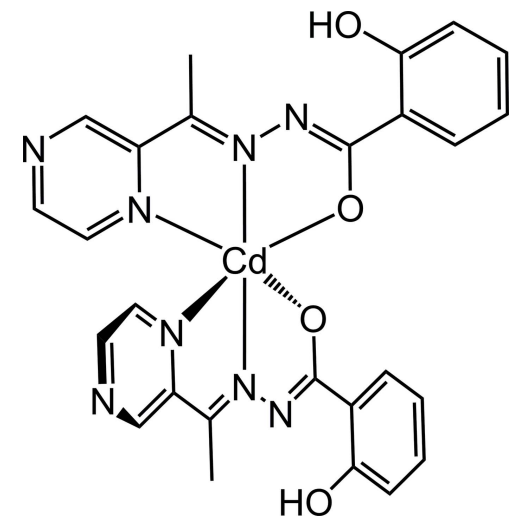


Table 1

Comparative analysis of ion radius and the bond lengths and bond angles of coordination polyhedra $\left(\AA{ }^{\circ}\right)$.

\begin{tabular}{|c|c|c|c|c|c|c|}
\hline & $\mathrm{Mn}^{2+}$ & $\mathrm{Co}^{2+}$ & $\mathrm{Ni}^{2+}$ & $\mathrm{Cu}^{2+}$ & $\mathrm{Zn}^{2+}$ & $\mathrm{Cd}^{2+}$ \\
\hline$M-\mathrm{N}$ & 2.283 & 2.151 & 2.114 & 2.192 & 2.215 & 2.356 \\
\hline$M-\mathrm{N}(\mathrm{mid})$ & 2.193 & 2.050 & 1.994 & 1.979 & 2.074 & 2.273 \\
\hline $\mathrm{N}(\mathrm{mid})-M-\mathrm{N}(\mathrm{mid})$ & 174.46 & 172.30 & 173.86 & 173.64 & 173.97 & 170.63 \\
\hline $\mathrm{N}-M-\mathrm{O}$ (within the same ligand) & 142.08 & 148.53 & 153.95 & 151.98 & 148.84 & 139.07 \\
\hline $\mathrm{O}-\mathrm{M}-\mathrm{O}$ & 99.76 & 102.86 & 95.26 & 97.43 & 98.87 & 95.39 \\
\hline
\end{tabular}

Notes: (a) Yang (2019); (b) Yang (2019); (c) Yang, Zhang et al. (2020); (d) Yang, Zhang et al. (2019); (e) Yang (2019); ( $f$ ) this work.

\section{Structural commentary}

In the title complex, the $\mathrm{Cd}^{2+}$ ion possesses a distorted octahedral $\mathrm{N}_{4} \mathrm{O}_{2}$ coordination environment, which is generated by the two deprotonated ligands $L$ (Fig. 1). The complex is bisected by a twofold crystallographic axis with the two ligands being equivalent by crystal symmetry. The complex is isomorphous to its $\mathrm{Mn}, \mathrm{Co}, \mathrm{Ni}, \mathrm{Cu}$ and $\mathrm{Zn}$ counterparts (Yang et al., 2019; Yang, Zhang et al., 2020). The $\mathrm{O} 2-\mathrm{C} 7$ and $\mathrm{C} 7-\mathrm{N} 1$ bond lengths in the title compound are 1.255(5) $\AA$ and 1.355 (5) $\AA$, respectively, indicating that the coordinated ligands are closer to the keto than the enol form, but are slightly more delocalized than in the purely keto tautomeric form as found in the free ligand form of similar aroylhydrazones. The free ligand $L$ has not yet been structurally described, but the equivalent bond distances in e.g. 2-hydroxy$N^{\prime}$-[1-(3-methylpyrazin-2-yl)ethylidene]benzohydrazide, $L^{1}$, with one more methyl group on pyrazine (Tai \& Feng, 2008), were reported as 1.235 and $1.340 \AA$, respectively.

The ligand in the title complex is close to planar (the mean deviation from the average plane is $0.0763 \AA$ ). The largest deviation from planarity is only 0.145 (3) $\AA$, observed for

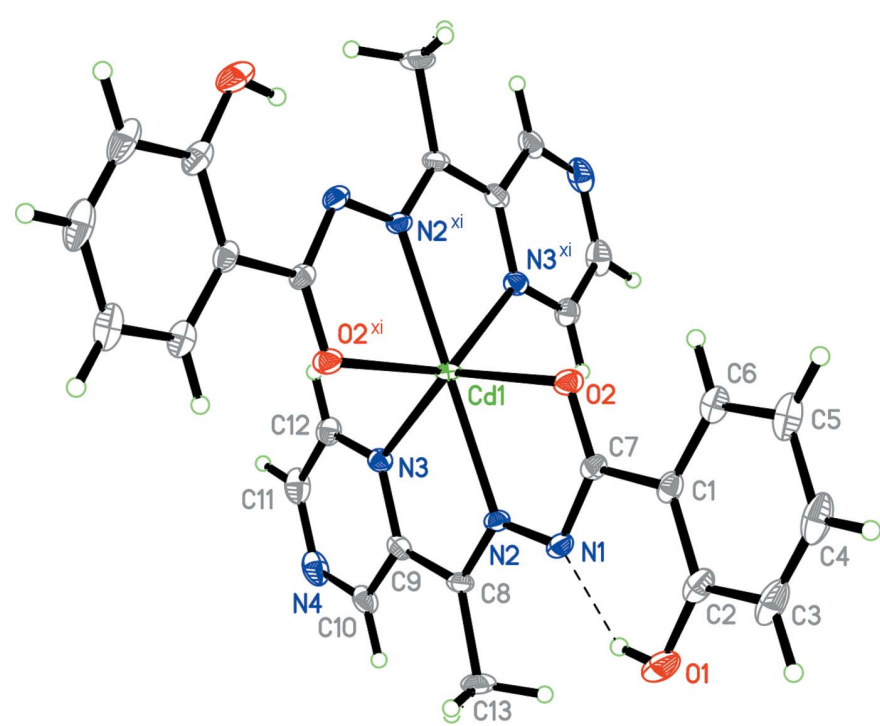

Figure 1

The molecular structure of $\left[\mathrm{Cd}\left(\mathrm{C}_{13} \mathrm{H}_{11} \mathrm{~N}_{4} \mathrm{O}_{2}\right)_{2}\right]$ with displacement ellipsoids at the $30 \%$ probability level. Symmetry code: $(\mathrm{xi})-x+1$, $-y+1, z$. atom $\mathrm{C} 12$ of the pyrazine ring. The $\mathrm{Cd} 1$ atom is nearly coplanar with each of the two ligands (deviation $=0.316 \AA$ ). The dihedral angle between the two ligands is $78.705(16)^{\circ}$. The oxygen atom $\mathrm{O} 1$ of the phenolic group remains protonated, and forms an intramolecular hydrogen bond $\mathrm{O} 1-$ $\mathrm{H} 1 \cdots \mathrm{N} 1\left[2.557(4) \AA, 146(7)^{\circ}\right]$.

The intramolecular hydrogen bond stabilizes the planar geometry of the ligand. The presence of the intramolecular hydrogen bond does also appear to affect the propensity of the metal complex towards crystallization. We found that when the hydroxyl group is in the meta or para position \{3-hydroxy$N^{\prime}$-[1-(pyrazin-2-yl)ethylidene]benzohydrazide $\left(L^{2}\right)$ or 4-hydroxy- $N^{\prime}$-[1-(pyrazin-2-yl)ethylidene]benzohydrazide $\left.\left(L^{3}\right)\right\}$, where no intramolecular hydrogen bond can be formed, crystallization is substantially delayed and a much longer time is required for the complexes to crystallize.

In the isomorphous $\mathrm{Mn}, \mathrm{Co}, \mathrm{Ni}, \mathrm{Cu}$ and $\mathrm{Zn} M(L)_{2}$ complexes, the ligands are also close to planar (the mean deviation from the average plane ranges from 0.0608 to $0.0754 \AA$ ). In dimethylformamide (DMF)-solvated $\mathrm{Ni}$ and $\mathrm{Cu}$ complexes of similar ligands $L^{2}$ \{3-hydroxy- $N^{\prime}$-[1-(pyrazin-2yl)ethylidene]benzohydrazide $\}$ and $L^{3}\left\{4\right.$-hydroxy- $N^{\prime}$-[1-(pyrazin-2-yl)ethylidene]benzohydrazide $\left[M\left(L^{2}\right)_{2}\right] \cdot 2(\mathrm{DMF})(M=$ $\mathrm{Ni}, \mathrm{Cu}$ and $\mathrm{Zn})$ and $\left[\mathrm{Cu}\left(L^{3}\right)_{2}\right] \cdot 2(\mathrm{DMF})(M=\mathrm{Ni}$ and $\mathrm{Cu})$, the planarity of the ligands is reduced, with a mean deviation from the average plane between 0.2164 to $0.2290 \AA$.

In the title complex, the $\mathrm{Cd} 1-\mathrm{N} 3, \mathrm{Cd} 1-\mathrm{N} 2$ and $\mathrm{Cd} 1-\mathrm{O} 2$, bond lengths are 2.356 (3), 2.273 (3) and 2.277 (4) $\AA$, respectively, which are close to typical for $\mathrm{Cd}^{2+}$ complexes closely related to the title compound, such as bis $\left\{N^{\prime}\right.$-[1-(pyridin-2yl)ethylidene]benzohydrazidato\}cadmium(II) (Sen et al., 2005), bis $\{2$-[2-(pyridin-2-ylmethylene)hydrazine-1-carbonyl]benzenesulfonamide\}cadmium(II) (Sousa-Pedrares et al., 2008) and bis[ $N^{\prime}$-(2-hydroxybenzoyl)picolinohydrazonamide]cadmium(II) (Xu et al., 2014), bis $\left\{N^{\prime}\right.$-[di(pyridin-2-yl)methylene]benzohydrazidato\}cadmium(II) (Kuriakose et al., 2017) [the range of $\mathrm{N}-\mathrm{Cd}$ is $2.360(12)-2.4135$ (11) $\AA$, N(middle) -

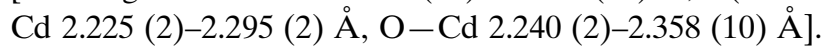

The coordination environment of the $\mathrm{Cd}$ ion is highly distorted octahedral, caused by the rigidity of the ligand and its small $\mathrm{N}-\mathrm{N}$ and $\mathrm{N}-\mathrm{O}$ bite angles of only 69.86 (11) (N3$\mathrm{Cd} 1-\mathrm{N} 2)$ and $69.83(11)^{\circ}(\mathrm{N} 2-\mathrm{Cd} 1-\mathrm{O} 2)$. As a result, the $\mathrm{N}-\mathrm{Cd}-\mathrm{O}, \mathrm{N}-\mathrm{Cd}-\mathrm{N}$ and $\mathrm{O}-\mathrm{Cd}-\mathrm{O}$ angles in the title compound deviate substantially from the values of 180 and $90^{\circ}$ 
Table 2

Hydrogen-bond geometry $\left(\AA,^{\circ}\right)$.

$C g 1$ and $C g 2$ are the centroids of the $\mathrm{C} 1-\mathrm{C} 6$ and $\mathrm{N} 3-\mathrm{N} 4 / \mathrm{C} 9-\mathrm{C} 12$ rings, respectively.

\begin{tabular}{lllll}
\hline$D-\mathrm{H} \cdots A$ & $D-\mathrm{H}$ & $\mathrm{H} \cdots A$ & $D \cdots A$ & $D-\mathrm{H} \cdots A$ \\
\hline $\mathrm{C} 4-\mathrm{H} 4 \cdots \mathrm{N} 4^{\mathrm{i}}$ & 0.95 & 2.47 & $3.349(6)$ & 154 \\
$\mathrm{C} 10-\mathrm{H} 10 \cdots \mathrm{O} 2^{\mathrm{ii}}$ & 0.95 & 2.55 & $3.283(5)$ & 134 \\
$\mathrm{C} 12-\mathrm{H} 12 \cdots \mathrm{O} 1^{\mathrm{iii}}$ & 0.95 & 2.49 & $3.439(5)$ & 174 \\
$\mathrm{O} 1-\mathrm{H} 1 \cdots \mathrm{N} 1$ & $0.90(8)$ & $1.76(8)$ & $2.557(4)$ & $146(7)$ \\
$\mathrm{C} 13-\mathrm{H} 13 A \cdots C g 2^{\text {iv }}$ & 0.98 & 2.86 & $3.740(6)$ & 149 \\
$\mathrm{C} 13-\mathrm{H} 13 B \cdots C g 1^{\mathrm{v}}$ & 0.98 & 2.71 & $3.592(6)$ & 150 \\
\hline
\end{tabular}

Symmetry codes: (i) $\quad-x+\frac{3}{2}, y+\frac{1}{2}, z+1$; (ii) $\quad x+\frac{1}{2},-y+1, z-\frac{1}{2}$; $\quad$ (iii) $x-\frac{1}{2},-y+1, z-\frac{1}{2} ;$ (iv) $-x+\frac{3}{2}, y, z+\frac{1}{2} ;\left(\right.$ v) $-x+\frac{3}{2}, y, z-\frac{1}{2}$.

expected for an idealized octahedral complex. The trans angles range from $139.07(10)$ to $170.63(17)^{\circ}$, while the cis angles vary between $69.83(11)$ and $117.27(11)^{\circ}$.

Bond distances and angles within the isomorphous series of the $\mathrm{Mn}, \mathrm{Co}, \mathrm{Ni}, \mathrm{Cu}, \mathrm{Zn}$, and $\mathrm{Cd}$ complexes follow a trend consistent with the metal ion radius (Table 1). Bond lengths first decrease and then increase, with a minimum value for the $\mathrm{Ni}$ or $\mathrm{Cu}$ complexes, and a maximum for the title cadmium complex as a result of its substantially larger ion radius as the only $4 d$ complex of the series. The trend of the $\mathrm{N}-M-\mathrm{O}$
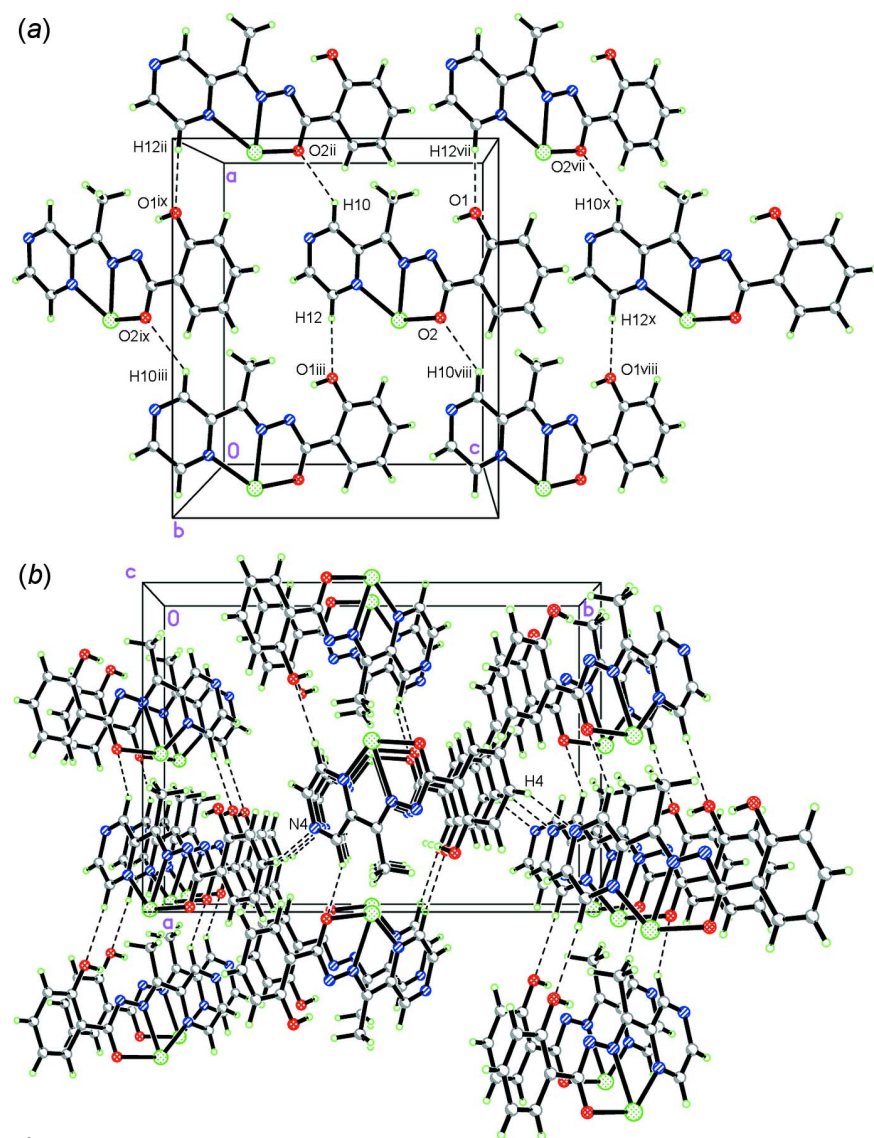

Figure 2

Crystal packing of the title compound showing the $\mathrm{O}-\mathrm{H} \cdots \mathrm{O}$ and $\mathrm{C}-$ $\mathrm{H} \cdots \mathrm{N}$ hydrogen bonds. For clarity, another symmetrical ligand coordinated with metal center has been omitted. Symmetry codes: (ii) $x+\frac{1}{2},-y+1, z-\frac{1}{2}$; (iii) $x-\frac{1}{2},-y+1, z-\frac{1}{2}$; (vii) $x+\frac{1}{2},-y+1, z+\frac{1}{2}$; (viii) $x-\frac{1}{2},-y+1, z+\frac{1}{2}$; (ix) $x, y, z-1$; (x) $x, y, z+1$. angle (within the same ligand) is opposite to that of the metal ion radius, and first increases and then decreases, with the maximum value appearing for the Ni complex (Brines et al., 2007; Reger et al., 2012; Sola et al., 1994; Database of Ionic Radii, 2020). The distortion from octahedral geometry increases with ion radius, and is most pronounced for the title cadmium complex, as can be seen for e.g. the $\mathrm{N}$ (mid) $-M-$ $\mathrm{N}$ (mid) angles, which range from 172.30 to $174.46^{\circ}$ for the $3 d$ complexes, while the value for the $4 d \mathrm{Cd}$ complex is $170.63(17)^{\circ}$.

\section{Supramolecular features}

Two types of weak intermolecular interactions, $\mathrm{C}-\mathrm{H} \cdots \mathrm{N}$ and $\mathrm{C}-\mathrm{H} \cdots \mathrm{O}$ hydrogen bonds and $\pi-\pi$ stacking and $\mathrm{C}-\mathrm{H} \cdots \pi$ interactions, have a significant impact on the packing of the complexes in the solid state. Three intermolecular hydrogen bonds (Table 2) are observed in the crystal. Two hydrogen
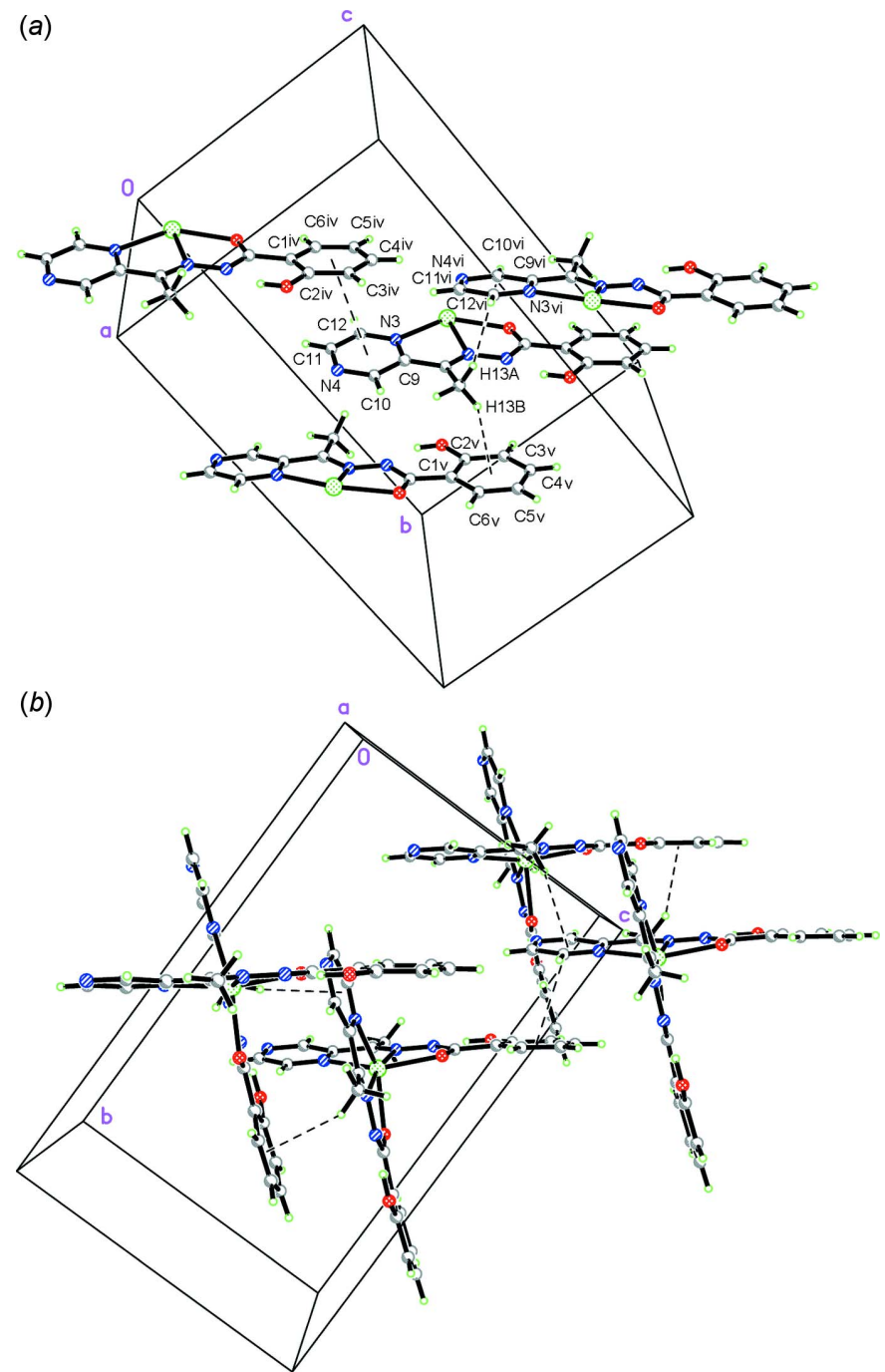

Figure 3

(a) Crystal packing of the title compound showing the $\mathrm{C}-\mathrm{H} \cdots \pi$ and $\pi-\pi$ interactions. For clarity, the second ligand at each metal centre has been omitted. Symmetry codes: (iv) $x, y-\frac{1}{2}, z-\frac{1}{2} ;$ (v) $-x+\frac{3}{2}, y, z-\frac{1}{2}$; (vi) $-x+\frac{3}{2}$, $y, z+\frac{1}{2} .(b)$ View down [100]. 
bonds $\left(\mathrm{C} 10-\mathrm{H} 10 \cdots \mathrm{O} 2^{\mathrm{ii}}\right.$ and $\mathrm{C} 12-\mathrm{H} 12 \cdots \mathrm{O} 1^{\mathrm{i}}$, symmetry code given in Table 2; Fig. 2a) form a sheet parallel to the crystallographic $b c$ plane. Adjacent sheets of the complex are connected to each other via a weak $\mathrm{C} 4-\mathrm{H} 4 \cdots \mathrm{N} 4^{\text {iii }}$ interaction, forming a three-dimensional network (Table 2 and Fig. $2 b$ ). Intermolecular $\pi-\pi$ stacking is observed between the pyrazine rings and benzene rings of ligands in neighbouring complexes [the centroid-centroid distance between N3-N4/ C9-C12 and C1-C6 ${ }^{\mathrm{vi}}$ [symmetry code: (vi) $x, y-\frac{1}{2}, z-\frac{1}{2}$ ] is 3.641 (2) $\AA$, with a slippage of $1.252 \AA$, Fig. 3. Intermolecular interactions between carbon atoms $\mathrm{C} 13$ and the $\pi$ ring of lateral benzene rings and pyrazine rings in neighbouring molecules are found, namely $\mathrm{C} 13-\mathrm{H} 13 B \cdots C g 1^{\mathrm{v}}[2.71 \AA$, $C g 1$ is the centroid of the C1-C6 ring; symmetry code: (v) $-x+\frac{3}{2}, y$, $\left.z-\frac{1}{2}\right]$ and $\mathrm{C} 13-\mathrm{H} 13 A \cdots C g 2^{\text {iv }}$ [2.86 $\mathrm{A}, C g 2$ is the centroid of the N3-N4/C9-C12; symmetry code: (iv) $\left.-x+\frac{3}{2}, y, z+\frac{1}{2}\right]$ (Fig. 3).

\section{Database survey}

A search of the Cambridge Structural Database (CSD, version 5.41, August 2020; Groom et al., 2016) for metal complexes involving the $N^{\prime}$-[1-(pyrazin-2-yl)ethylidene]benzohydrazide ligand resulted in seven related metal complexes with exactly the same ligand. These are the already discussed isomorphous $\mathrm{Mn}, \mathrm{Co}, \mathrm{Ni}, \mathrm{Cu}$ and $\mathrm{Zn}\left[M^{\mathrm{II}}(L)_{2}\right]$ complexes (CCDC refcodes: CIZJED for $M=\mathrm{Mn}$, CIZGOK for $M=\mathrm{Co}$, CIZGAW for $M=$ Ni (Yang, Zhang et al., 2020), COYVUK for $M=\mathrm{Cu}$ and CIZFUP for $M=\mathrm{Zn}$ ) (Yang et al., 2019). In all of these complexes, the ligand $L$ acts as a tridentate chelating ligand to generate a distorted octahedral structure with a close to planar ligand. Several complexes of related ligands have been found to be also isomorphous to the above series, crystallizing in the same $A b a 2$ space group. These are a Co and a $\mathrm{Zn}$ complex bearing the ligand $N^{\prime}$-[1-(pyrazin-2-yl)ethylidene]benzohydrazide ( $L^{4}$, with one less hydroxyl group on benzene) (YELKUY, YELWUK; Tai et al., 2008) as well as four metal complexes involving the ligand 2-hydroxy- $N^{\prime}$-[1-(pyridin-2yl)ethylidene]benzohydrazide ( $L^{5}$, substituted pyrazine group with pyridine group) with $M=\mathrm{Cu}^{2+}, \mathrm{Ni}^{2+}, \mathrm{Zn}^{2+}$ and $\mathrm{Fe}^{2+}$ [ADEYAK (Dang et al., 2006a); XENFEC (Dang et al., 2006b); HIGPOD (Barbazán et al., 2007); RADDOR (Zhang et al., 2010)].

There are also complexes of ligands $L^{4}$ and $L^{5}$ that are not isomorphous to the title complex: complex $\mathrm{Cu}_{2}\left(L^{4}\right)_{2} \mathrm{Cl}_{2}$ is binuclear, where each $\mathrm{Cu}$ centre has two $\mu$-chlorine ligands along with a tridentate coordinated $L^{4}$ molecule, giving rise to a distorted square-pyramidal coordination environment. It belongs to the triclinic $P \overline{1}$ space group (YELXAR; Tai et al., 2008). The cobalt complex $\left[\mathrm{Co}\left(L^{5}\right)_{2}\left(\mathrm{ClO}_{4}\right)\right] \cdot 0.25\left(\mathrm{CH}_{3} \mathrm{OH}\right)$ (IGAZAS; Shit et al., 2009) has a nearly ideal octahedral structure in the monoclinic $P 2_{1} / n$ space group, and the ligands have $\mathrm{N}-\mathrm{N}$ and $\mathrm{N}-\mathrm{O}$ bite angles of 81.70 to $83.11^{\circ} . \mathrm{Cu}\left(L^{5}\right) \mathrm{Br}$ (HIGPIX; Barbazán et al., 2007) and $\mathrm{Cu}\left(L^{5}\right)\left(\mathrm{NO}_{3}\right)$ (YILYEY; You et al., 2018) have roughly square-planar coordination geometries. $\left[\mathrm{Sb}\left(L^{5}\right) \mathrm{Cl}_{2}\right] \cdot \mathrm{H}_{2} \mathrm{O}$ (YILYEY; Abboud et al., 2007) has a square-pyramidal coordination geometry in the mono- clinic $P 2_{1} / n$ space group. $\mathrm{Cu}_{2}\left(L^{5}\right)_{2} \mathrm{Cl}_{2}$ (NICYOP; Mondal et al., 2013) is a binuclear complex and each $\mathrm{Cu}$ centre has a squarepyramidal coordination geometry. It is isomorphic to $\mathrm{Cu}_{2}\left(L^{4}\right)_{2} \mathrm{Cl}_{2}$. A $\mathrm{Zn}$ complex, $\mathrm{Zn}\left(L^{1}\right)_{2} \cdot \mathrm{H}_{2} \mathrm{O}$ (XIYNUP; Tai et al., 2008) with the ligand $L^{1}$ with one more methyl group on pyrazine crystallizes in the monoclinic $P 2_{1} / n$ space group. The planarity of the ligand is decreased compared to the title complex, and the $\mathrm{Zn}$ ion exhibits a distorted octahedral geometry. Also reported are five similar compounds featuring the ligands $L^{2}$ and $L^{3}$ with the hydroxyl group in the meta and para positions of the benzene ring, respectively. They crystallize as DMF solvates $\left[M\left(L^{2}\right)_{2}\right] \cdot 2(\mathrm{DMF})(\mathrm{DMF}=$ dimethylformamide; $M=\mathrm{Ni}, \mathrm{Cu}$ and $\mathrm{Zn}$; CIZHIF, CIZGUQ and CIZJAZ) and $\left[\mathrm{Cu}\left(L^{3}\right)_{2}\right] \cdot 2(\mathrm{DMF})(M=\mathrm{Ni}$ and $\mathrm{Cu}$; CIZHUR and COYWEV) (Yang et al., 2019; Yang, Zhang et al., 2020) in the orthorhombic Pbcn space group. They also feature distorted octahedral structures and the planarity of the ligands is decreased compared to the title compound. All the complexes with the $\left[M(\text { Ligand })_{2}\right]$ core are distorted octahedral, and all metal centres have a mer geometry. All ligands $L, L^{1}, L^{2}, L^{3}, L^{4}$ and $L^{5}$ are tridentate chelating.

\section{Synthesis and crystallization}

The title complex and ligand were synthesized according to literature procedures (Yang, Zhang et al., 2020; Yang et al., 2019). The complex was obtained by mixing a solution of the aroylhydrazone $(0.02 \mathrm{mmol})$ in methanol $(2 \mathrm{~mL})$ and a solution of $\mathrm{Cd}\left(\mathrm{NO}_{3}\right)_{2} \cdot 4 \mathrm{H}_{2} \mathrm{O}(0.01 \mathrm{mmol})$ in water $(2 \mathrm{~mL})$. After two weeks of static volatilization in a test tube at room temperature, clear light-yellow block-shaped crystals of $\mathrm{Cd}(L)_{2}$ were obtained $(5.6 \mathrm{mg}$, yield $90 \%$ ) (calculated based on metal ions), m.p. > $543 \mathrm{~K}$. IR (KBr): $v\left(\mathrm{~cm}^{-1}\right)=1594 s, 1534$ $s, 1518 s, 1489 s, 1458 s, 1401 w, 1349 s, 1299 s, 1248 m, 1225 m$, $1198 m, 1162 m, 1147 s, 1106 w, 1072 s, 1042 m, 1029 m, 910 w$, $850 w, 833 w, 786 w, 764 m, 701 m, 662 w, 565 w, 541 w, 492 w$, $419 w, 406 w$.

\section{Refinement}

Crystal data, data collection and structure refinement details are summarized in Table 3. All C-bound $\mathrm{H}$ atoms were placed in calculated positions $\left(\mathrm{Csp}^{2}-\mathrm{H}=0.95 \AA\right.$ and $\mathrm{Csp} p^{3}-\mathrm{H}=$ $0.98 \AA$ ) and were included in the refinement in a riding-model approximation, with $U_{\text {iso }}(\mathrm{H})$ set to $1.2 U_{\text {eq }}\left(\mathrm{Csp}^{2}\right)$ and $1.5 U_{\text {eq }}\left(\mathrm{Csp}^{3}\right)$. The $\mathrm{O}$-bound $\mathrm{H}$ atom was located based on a difference-Fourier map and its position was freely refined. It was assigned $U_{\text {iso }}(\mathrm{H})=1.5 U_{\text {eq }}(\mathrm{O})$.

\section{Acknowledgements}

The authors thank Guangzhou University and Zi-Zhou Wang for recording the $\mathrm{X}$-ray crystallographic data for the crystals.

\section{Funding information}

Funding for this research was provided by: the National Natural Science Foundation of China (grant No. 41701349); 
Table 3

Experimental details.

\begin{tabular}{|c|c|}
\hline \multicolumn{2}{|l|}{ Crystal data } \\
\hline Chemical formula & {$\left[\mathrm{Cd}\left(\mathrm{C}_{13} \mathrm{H}_{11} \mathrm{~N}_{4} \mathrm{O}_{2}\right)_{2}\right]$} \\
\hline$M_{\mathrm{r}}$ & 622.91 \\
\hline Crystal system, space group & Orthorhombic, $A b a 2$ \\
\hline Temperature $(\mathrm{K})$ & 108 \\
\hline$a, b, c(\AA)$ & $\begin{array}{l}12.6654(1), 17.63940(18), \\
10.88800(11)\end{array}$ \\
\hline$V\left(\AA^{3}\right)$ & $2432.49(4)$ \\
\hline$Z$ & 4 \\
\hline Radiation type & $\mathrm{Cu} \mathrm{K \alpha}$ \\
\hline$\mu\left(\mathrm{mm}^{-1}\right)$ & 7.64 \\
\hline Crystal size (mm) & $0.12 \times 0.10 \times 0.08$ \\
\hline \multicolumn{2}{|l|}{ Data collection } \\
\hline Diffractometer & $\begin{array}{l}\text { Rigaku Oxford Diffraction } \\
\text { XtaLAB Synergy R, DW system, } \\
\text { HyPix }\end{array}$ \\
\hline Absorption correction & $\begin{array}{l}\text { Multi-scan (CrysAlis PRO; Rigaku } \\
\text { OD, 2020) }\end{array}$ \\
\hline$T_{\min }, T_{\max }$ & $0.519,1.000$ \\
\hline $\begin{array}{l}\text { No. of measured, independent and } \\
\text { observed }[I>2 \sigma(I)] \text { reflections }\end{array}$ & $36223,2475,2458$ \\
\hline$R_{\text {int }}$ & 0.038 \\
\hline$(\sin \theta / \lambda)_{\max }\left(\AA^{-1}\right)$ & 0.630 \\
\hline \multicolumn{2}{|l|}{ Refinement } \\
\hline$R\left[F^{2}>2 \sigma\left(F^{2}\right)\right], w R\left(F^{2}\right), S$ & $0.026,0.075,1.20$ \\
\hline No. of reflections & 2475 \\
\hline No. of parameters & 182 \\
\hline No. of restraints & 1 \\
\hline $\mathrm{H}$-atom treatment & $\begin{array}{l}\mathrm{H} \text { atoms treated by a mixture of } \\
\text { independent and constrained } \\
\text { refinement }\end{array}$ \\
\hline$\Delta \rho_{\max }, \Delta \rho_{\min }\left(\mathrm{e} \AA^{-3}\right)$ & $0.72,-0.99$ \\
\hline Absolute structure & $\begin{array}{l}\text { Flack } x \text { determined using } 1131 \\
\text { quotients }\left[\left(I^{+}\right)-\left(I^{-}\right)\right] /\left[\left(I^{+}\right)+\left(I^{-}\right)\right] \\
\text {(Parsons et al., 2013). }\end{array}$ \\
\hline Absolute structure parameter & $-0.012(4)$ \\
\hline
\end{tabular}

Computer programs: CrysAlis PRO (Rigaku OD, 2020), SHELXS and SHELXP (Sheldrick, 2008), SHELXL (Sheldrick, 2015) and publCIF (Westrip, 2010).

GDAS' Project of Science and Technology Development (grant No. 2020GDASYL-20200103015); Nanyue Talent Fund (grant No. GDIMYET20180205).

\section{References}

Abboud, K. A., Palenik, R. C., Palenik, G. J. \& Wood, R. M. (2007). Inorg. Chim. Acta, 360, 3642-3646.

Barbazán, P., Carballo, R. \& Vázquez-López, E. M. (2007). CrystEngComm, 9, 668-675.

Brines, L. M., Shearer, J., Fender, J. K., Schweitzer, D., Shoner, S. C., Barnhart, D., Kaminsky, W., Lovell, S. \& Kovacs, J. A. (2007). Inorg. Chem. 46, 9267-9277.

Cindrić, M., Bjelopetrović, A., Pavlović, G., Damjanović, V., Lovrić, J., Matković-Čalogović, D. \& Vrdoljak, V. (2017). New J. Chem. 41, 2425-2435.

Dang, D.-B., Bai, Y. \& Duan, C.-Y. (2006a). Acta Cryst. E62, m1567m1568.
Dang, D.-B., Bai, Y. \& Duan, C.-Y. (2006b). Acta Cryst. E62, m2290$\mathrm{m} 2292$.

Database of Ionic Radii (2020). Hosted by the Atomistic Simulation Group in the Materials Department of Imperial College, http:// abulafia.mt.ic.ac.uk/shannon/PTABLE.php

Groom, C. R., Bruno, I. J., Lightfoot, M. P. \& Ward, S. C. (2016). Acta Cryst. B72, 171-179.

Huang, W., Shen, F.-X., Wu, S.-Q., Liu, L., Wu, D., Zheng, Z., Xu, J., Zhang, M., Huang, X.-C., Jiang, J., Pan, F., Li, Y., Zhu, K. \& Sato, O. (2016). Inorg. Chem. 55, 5476-5484.

Kalinowski, D. S., Sharpe, P. C., Bernhardt, P. V. \& Richardson, D. R. (2008). J. Med. Chem. 51, 331-344.

Kar, C., Samanta, S., Goswami, S., Ramesh, A. \& Das, G. (2015). Dalton Trans. 44, 4123-4132.

Kuriakose, D., Aravindakshan, A. A. \& Kurup, M. R. P. (2017). Polyhedron, 127, 84-96.

Manna, A. K., Chowdhury, S. \& Patra, G. K. (2019). Dalton Trans. 48, 12336-12348.

Mondal, S., Naskar, S., Dey, A. K., Sinn, E., Eribal, C., Herron, S. R. \& Chattopadhyay, S. K. (2013). Inorg. Chim. Acta, 398, 98-105.

Parsons, S., Flack, H. D. \& Wagner, T. (2013). Acta Cryst. B69, 249259.

Patel, R. N., Singh, Y., Singh, Y. P., Patel, A. K., Patel, N., Singh, R., Butcher, R. J., Jasinski, J. P., Colacio, E. \& Palacios, M. A. (2018). New J. Chem. 42, 3112-3136.

Reger, D. L., Pascui, A. E., Smith, M. D., Jezierska, J. \& Ozarowski, A. (2012). Inorg. Chem. 51, 11820-11836.

Rigaku OD (2020). CrysAlis PRO. Rigaku Oxford Diffraction, Yarnton, England.

Sen, S., Talukder, P., Rosair, G. \& Mitra, S. (2005). Struct. Chem. 16, 605-610.

Sheldrick, G. M. (2008). Acta Cryst. A64, 112-122.

Sheldrick, G. M. (2015). Acta Cryst. C71, 3-8.

Shit, S., Chakraborty, J., Samanta, B., Slawin, A. M. Z., Gramlich, V. \& Mitra, S. (2009). Struct. Chem. 20, 633-642.

Sola, M., Mestres, J., Duran, M. \& Carbo, R. (1994). J. Chem. Inf. Comput. Sci. 34, 1047-1053.

Sousa-Pedrares, A., Camiña, N., Romero, J., Durán, M. L., GarcíaVázquez, J. A. \& Sousa, A. (2008). Polyhedron, 27, 33913397.

Sutradhar, M., Kirillova, M. V., Guedes da Silva, M. F. C., Liu, C.-M. \& Pombeiro, A. J. L. (2013). Dalton Trans. 42, 16578-16587.

Tai, X.-S. \& Feng, Y.-M. (2008). Acta Cryst. E64, o707-o707.

Tai, X.-S., Feng, Y.-M. \& Zhang, H.-X. (2008). Acta Cryst. E64, m656. Westrip, S. P. (2010). J. Appl. Cryst. 43, 920-925.

Xu, S.-P., Yang, F.-L., Zhu, G.-Z., Shi, H.-L. \& Li, X.-L. (2014). Polyhedron, 68, 1-9.

Yang, P. (2019). CSD Communications (refcodes CIZJED, CIZGOK and CIZFUP). CCDC, Cambridge, England.

Yang, P., Chen, H., Wang, Z.-Z., Zhang, L.-L., Zhang, D.-D., Shi, Q.-S. \& Xie, X.-B. (2020). J. Inorg. Biochem. 213, 111248-111248.

Yang, P., Zhang, D.-D., Wang, Z.-Z., Liu, H.-Z., Shi, Q.-S. \& Xie, X.-B. (2019). Dalton Trans. 48, 17925-17935.

Yang, P., Zhang, L.-L., Wang, Z.-Z., Zhang, D.-D., Liu, Y.-M., Shi, Q.-S. \& Xie, X.-B. (2020). J. Inorg. Biochem. 203, 110919110919.

You, Z., Yu, H., Li, Z., Zhai, W., Jiang, Y., Li, A., Guo, S., Li, K., Lv, C. \& Zhang, C. (2018). Inorg. Chim. Acta, 480, 120-126.

Zhang, L., Xu, G.-C., Xu, H.-B., Mereacre, V., Wang, Z.-M., Powell, A. K. \& Gao, S. (2010). Dalton Trans. 39, 4856-4868. 


\section{supporting information}

Acta Cryst. (2021). E77, 153-157 [https://doi.org/10.1107/S2056989021000657]

Crystal structure of bis\{2-hydroxy-N'-[1-(pyrazin-2-yl)ethylidene]benzohydrazidato\}cadmium(II)

\section{Ping Yang, Xiao-Bao Xie and Qing-Shan Shi}

Computing details

Data collection: CrysAlis PRO (Rigaku OD, 2020); cell refinement: CrysAlis PRO (Rigaku OD, 2020); data reduction: CrysAlis PRO (Rigaku OD, 2020); program(s) used to solve structure: SHELXS (Sheldrick, 2008); program(s) used to refine structure: SHELXL (Sheldrick, 2015); molecular graphics: SHELXP (Sheldrick, 2008); software used to prepare material for publication: publCIF (Westrip, 2010).

Bis\{2-hydroxy-N'-[1-(pyrazin-2-yl)ethylidene]benzohydrazidato\}cadmium(II)

\section{Crystal data}

$\left[\mathrm{Cd}\left(\mathrm{C}_{13} \mathrm{H}_{11} \mathrm{~N}_{4} \mathrm{O}_{2}\right)_{2}\right]$

$M_{r}=622.91$

Orthorhombic, $A b a 2$

$a=12.6654(1) \AA$

$b=17.63940(18) \AA$

$c=10.88800(11) \AA$

$V=2432.49(4) \AA^{3}$

$Z=4$

$F(000)=1256$

Data collection

Rigaku Oxford Diffraction XtaLAB Synergy R, DW system, HyPix

diffractometer

Radiation source: Rotating-anode X-ray tube

Detector resolution: 10.0000 pixels $\mathrm{mm}^{-1}$

$\omega$ scans

Absorption correction: multi-scan

(CrysAlisPro; Rigaku OD, 2020)

$T_{\min }=0.519, T_{\max }=1.000$

Refinement

Refinement on $F^{2}$

Least-squares matrix: full

$R\left[F^{2}>2 \sigma\left(F^{2}\right)\right]=0.026$

$w R\left(F^{2}\right)=0.075$

$S=1.20$

2475 reflections

182 parameters

1 restraint
$D_{\mathrm{x}}=1.701 \mathrm{Mg} \mathrm{m}^{-3}$

$\mathrm{Cu} K \alpha$ radiation, $\lambda=1.54178 \AA$

Cell parameters from 31744 reflections

$\theta=2.5-76.5^{\circ}$

$\mu=7.64 \mathrm{~mm}^{-1}$

$T=108 \mathrm{~K}$

Block, clear light yellow

$0.12 \times 0.10 \times 0.08 \mathrm{~mm}$

36223 measured reflections

2475 independent reflections

2458 reflections with $I>2 \sigma(I)$

$R_{\text {int }}=0.038$

$\theta_{\max }=76.2^{\circ}, \theta_{\min }=5.0^{\circ}$

$h=-14 \rightarrow 15$

$k=-21 \rightarrow 22$

$l=-13 \rightarrow 13$
Primary atom site location: structure-invariant direct methods

Secondary atom site location: difference Fourier map

Hydrogen site location: mixed

$\mathrm{H}$ atoms treated by a mixture of independent and constrained refinement

$w=1 /\left[\sigma^{2}\left(F_{\mathrm{o}}^{2}\right)+(0.0473 P)^{2}+1.8799 P\right]$ where $P=\left(F_{\mathrm{o}}^{2}+2 F_{\mathrm{c}}{ }^{2}\right) / 3$ 
$(\Delta / \sigma)_{\max }<0.001$

$\Delta \rho_{\max }=0.72$ e $\AA^{-3}$

$\Delta \rho_{\min }=-0.99$ e $\AA^{-3}$

Extinction correction: SHELXL (Sheldrick, 2015), $\mathrm{Fc}^{*}=\mathrm{kFc}\left[1+0.001 \times \mathrm{Fc}^{2} \lambda^{3} / \sin (2 \theta)\right]^{-1 / 4}$
Extinction coefficient: 0.00067 (9)

Absolute structure: Flack $x$ determined using

1131 quotients $\left[\left(I^{+}\right)-(I)\right] /\left[\left(I^{+}\right)+(I)\right]$ (Parsons et al., 2013).

Absolute structure parameter: -0.012 (4)

Special details

Geometry. All esds (except the esd in the dihedral angle between two 1.s. planes) are estimated using the full covariance matrix. The cell esds are taken into account individually in the estimation of esds in distances, angles and torsion angles; correlations between esds in cell parameters are only used when they are defined by crystal symmetry. An approximate (isotropic) treatment of cell esds is used for estimating esds involving l.s. planes.

Fractional atomic coordinates and isotropic or equivalent isotropic displacement parameters $\left(\AA^{2}\right)$

\begin{tabular}{|c|c|c|c|c|}
\hline & $x$ & $y$ & $z$ & $U_{\text {iso }} * / U_{\text {eq }}$ \\
\hline $\mathrm{C} 1$ & $0.6224(3)$ & $0.6694(2)$ & $0.9539(4)$ & $0.0255(8)$ \\
\hline $\mathrm{C} 2$ & $0.7242(3)$ & $0.6887(2)$ & $0.9964(4)$ & $0.0322(9)$ \\
\hline $\mathrm{C} 3$ & $0.7340(5)$ & $0.7364(3)$ & $1.0986(5)$ & $0.0422(13)$ \\
\hline $\mathrm{H} 3$ & 0.802253 & 0.749817 & 1.127537 & $0.051 *$ \\
\hline $\mathrm{C} 4$ & $0.6462(5)$ & $0.7642(2)$ & $1.1578(4)$ & 0.0439 (12) \\
\hline $\mathrm{H} 4$ & 0.654329 & 0.795728 & 1.227906 & $0.053 *$ \\
\hline $\mathrm{C} 5$ & $0.5452(5)$ & $0.7465(2)$ & $1.1153(4)$ & $0.0399(11)$ \\
\hline H5 & 0.484590 & 0.766539 & 1.155165 & $0.048^{*}$ \\
\hline C6 & $0.5341(4)$ & $0.6995(2)$ & $1.0149(4)$ & $0.0316(8)$ \\
\hline H6 & 0.465320 & 0.687281 & 0.986326 & $0.038^{*}$ \\
\hline $\mathrm{C} 7$ & $0.6043(3)$ & 0.61456 (19) & $0.8526(3)$ & $0.0220(7)$ \\
\hline $\mathrm{C} 8$ & $0.7448(4)$ & $0.5100(2)$ & $0.6398(5)$ & $0.0240(9)$ \\
\hline C9 & 0.7096 & $0.4582(2)$ & $0.5418(4)$ & $0.0247(8)$ \\
\hline $\mathrm{C} 10$ & 0.7783 & $0.4270(2)$ & $0.4540(4)$ & $0.0319(9)$ \\
\hline H10 & 0.851195 & 0.439329 & 0.458193 & $0.038 *$ \\
\hline C11 & $0.6425(4)$ & $0.3646(2)$ & $0.3636(4)$ & $0.0365(10)$ \\
\hline H11 & 0.616344 & 0.331030 & 0.302482 & $0.044 *$ \\
\hline $\mathrm{C} 12$ & $0.5728(3)$ & $0.3950(2)$ & $0.4482(4)$ & $0.0282(8)$ \\
\hline H12 & 0.500036 & 0.382194 & 0.443503 & $0.034 *$ \\
\hline $\mathrm{C} 13$ & $0.8597(3)$ & $0.5252(3)$ & $0.6647(5)$ & $0.0388(11)$ \\
\hline $\mathrm{H} 13 \mathrm{~A}$ & 0.879522 & 0.502577 & 0.743598 & $0.058 *$ \\
\hline H13B & 0.871828 & 0.580037 & 0.667603 & $0.058 *$ \\
\hline $\mathrm{H} 13 \mathrm{C}$ & 0.902554 & 0.502866 & 0.599080 & $0.058 *$ \\
\hline $\mathrm{Cd} 1$ & 0.500000 & 0.500000 & $0.68642(13)$ & $0.01811(16)$ \\
\hline N1 & $0.6931(3)$ & $0.58932(17)$ & $0.7964(3)$ & $0.0236(6)$ \\
\hline $\mathrm{N} 2$ & $0.6699(2)$ & $0.54015(16)$ & 0.7035 & $0.0211(6)$ \\
\hline N3 & $0.6056(2)$ & $0.44157(17)$ & 0.5356 & $0.0227(6)$ \\
\hline N4 & $0.7454(4)$ & $0.3809(2)$ & $0.3652(4)$ & $0.0398(9)$ \\
\hline $\mathrm{O} 1$ & 0.8136 & $0.66287(19)$ & $0.9425(3)$ & $0.0393(7)$ \\
\hline $\mathrm{H} 1$ & $0.796(6)$ & $0.631(4)$ & $0.880(7)$ & $0.059 *$ \\
\hline $\mathrm{O} 2$ & $0.5115(2)$ & $0.5951(2)$ & $0.8272(4)$ & $0.0271(8)$ \\
\hline
\end{tabular}


Atomic displacement parameters $\left(\AA^{2}\right)$

\begin{tabular}{lllllll}
\hline & $U^{11}$ & $U^{22}$ & $U^{33}$ & $U^{12}$ & $U^{13}$ & $U^{23}$ \\
\hline C1 & $0.031(2)$ & $0.0204(17)$ & $0.0249(18)$ & $-0.0051(13)$ & $-0.0068(15)$ & $0.0044(15)$ \\
C2 & $0.039(2)$ & $0.0289(18)$ & $0.0291(19)$ & $-0.0115(17)$ & $-0.0106(18)$ & $0.0059(16)$ \\
C3 & $0.062(3)$ & $0.0319(18)$ & $0.032(2)$ & $-0.019(2)$ & $-0.020(2)$ & $0.004(2)$ \\
C4 & $0.076(4)$ & $0.029(2)$ & $0.026(2)$ & $-0.015(2)$ & $-0.010(2)$ & $-0.0013(17)$ \\
C5 & $0.064(4)$ & $0.025(2)$ & $0.030(2)$ & $-0.010(2)$ & $0.000(2)$ & $-0.0017(18)$ \\
C6 & $0.041(2)$ & $0.0249(19)$ & $0.028(2)$ & $-0.0056(19)$ & $-0.003(2)$ & $-0.0002(16)$ \\
C7 & $0.0221(17)$ & $0.0225(16)$ & $0.0214(16)$ & $-0.0039(13)$ & $-0.0030(14)$ & $0.0033(14)$ \\
C8 & $0.014(2)$ & $0.0278(18)$ & $0.031(2)$ & $0.0012(15)$ & $0.0002(18)$ & $0.0100(16)$ \\
C9 & $0.0225(19)$ & $0.0237(16)$ & $0.0279(18)$ & $0.0048(13)$ & $0.0074(15)$ & $0.0079(14)$ \\
C10 & $0.030(2)$ & $0.0273(18)$ & $0.038(2)$ & $0.0084(15)$ & $0.0141(17)$ & $0.0076(17)$ \\
C11 & $0.055(3)$ & $0.0276(19)$ & $0.027(2)$ & $0.0030(19)$ & $0.010(2)$ & $-0.0020(16)$ \\
C12 & $0.033(2)$ & $0.0258(17)$ & $0.0261(17)$ & $-0.0022(15)$ & $0.0027(16)$ & $0.0024(16)$ \\
C13 & $0.0136(18)$ & $0.045(2)$ & $0.058(3)$ & $-0.0028(18)$ & $0.0024(19)$ & $0.010(3)$ \\
Cd1 & $0.0110(2)$ & $0.0243(2)$ & $0.0190(2)$ & $-0.00150(9)$ & 0.000 & 0.000 \\
N1 & $0.0208(15)$ & $0.0243(15)$ & $0.0256(15)$ & $-0.0053(12)$ & $-0.0046(12)$ & $0.0016(12)$ \\
N2 & $0.0155(14)$ & $0.0234(12)$ & $0.0243(16)$ & $-0.0022(11)$ & $0.0008(12)$ & $0.0048(12)$ \\
N3 & $0.0207(15)$ & $0.0243(14)$ & $0.0230(13)$ & $0.0016(11)$ & $0.0039(12)$ & $0.0029(12)$ \\
N4 & $0.049(2)$ & $0.0302(17)$ & $0.040(2)$ & $0.0100(17)$ & $0.0206(18)$ & $0.0047(16)$ \\
O1 & $0.0320(17)$ & $0.0460(17)$ & $0.0399(16)$ & $-0.0136(13)$ & $-0.0121(14)$ & $0.0016(15)$ \\
O2 & $0.0208(14)$ & $0.0311(17)$ & $0.0293(18)$ & $-0.0023(10)$ & $-0.0010(11)$ & $-0.0091(15)$ \\
& & & & & & \\
\hline
\end{tabular}

Geometric parameters $\left(\AA,{ }^{\circ}\right)$

\begin{tabular}{llll}
\hline $\mathrm{C} 1-\mathrm{C} 6$ & $1.405(7)$ & $\mathrm{C} 10-\mathrm{N} 4$ & $1.330(7)$ \\
$\mathrm{C} 1-\mathrm{C} 2$ & $1.412(6)$ & $\mathrm{C} 10-\mathrm{H} 10$ & 0.9500 \\
$\mathrm{C} 1-\mathrm{C} 7$ & $1.485(5)$ & $\mathrm{C} 11-\mathrm{N} 4$ & $1.335(7)$ \\
$\mathrm{C} 2-\mathrm{O} 1$ & $1.354(6)$ & $\mathrm{C} 11-\mathrm{C} 12$ & $1.385(6)$ \\
$\mathrm{C} 2-\mathrm{C} 3$ & $1.401(7)$ & $\mathrm{C} 11-\mathrm{H} 11$ & 0.9500 \\
$\mathrm{C} 3-\mathrm{C} 4$ & $1.375(8)$ & $\mathrm{C} 12-\mathrm{N} 3$ & $1.324(5)$ \\
$\mathrm{C} 3-\mathrm{H} 3$ & 0.9500 & $\mathrm{C} 12-\mathrm{H} 12$ & 0.9500 \\
$\mathrm{C} 4-\mathrm{C} 5$ & $1.396(8)$ & $\mathrm{C} 13-\mathrm{H} 13 \mathrm{~A}$ & 0.9800 \\
$\mathrm{C} 4-\mathrm{H} 4$ & 0.9500 & $\mathrm{C} 13-\mathrm{H} 13 \mathrm{~B}$ & 0.9800 \\
$\mathrm{C} 5-\mathrm{C} 6$ & $1.378(6)$ & $\mathrm{C} 13-\mathrm{H} 13 \mathrm{C}$ & 0.9800 \\
$\mathrm{C} 5-\mathrm{H} 5$ & 0.9500 & $\mathrm{Cd} 1-\mathrm{N} 2$ & $2.273(3)$ \\
$\mathrm{C} 6-\mathrm{H} 6$ & 0.9500 & $\mathrm{Cd} 1-\mathrm{N} 2^{\mathrm{i}}$ & $2.273(3)$ \\
$\mathrm{C} 7-\mathrm{O} 2$ & $1.255(5)$ & $\mathrm{Cd} 1-\mathrm{O} 2$ & $2.277(4)$ \\
$\mathrm{C} 7-\mathrm{N} 1$ & $1.355(5)$ & $\mathrm{Cd} 1-\mathrm{O} 2^{\mathrm{i}}$ & $2.277(4)$ \\
$\mathrm{C} 8-\mathrm{N} 2$ & $1.289(6)$ & $\mathrm{Cd} 1-\mathrm{N} 3^{\mathrm{i}}$ & $2.356(3)$ \\
$\mathrm{C} 8-\mathrm{C} 9$ & $1.475(7)$ & $\mathrm{Cd} 1-\mathrm{N} 3$ & $2.356(3)$ \\
$\mathrm{C} 8-\mathrm{C} 13$ & $1.504(7)$ & $\mathrm{N} 1-\mathrm{N} 2$ & $1.365(4)$ \\
$\mathrm{C} 9-\mathrm{N} 3$ & $1.351(5)$ & $\mathrm{O} 1-\mathrm{H} 1$ & $0.90(8)$ \\
$\mathrm{C} 9-\mathrm{C} 10$ & $1.405(5)$ & & 119.4 \\
$\mathrm{C} 6-\mathrm{C} 1-\mathrm{C} 2$ & & & 119.4 \\
$\mathrm{C} 6-\mathrm{C} 1-\mathrm{C} 7$ & $118.7(4)$ & $\mathrm{N} 3-\mathrm{C} 12-\mathrm{H} 12$ & $\mathrm{C} 11-\mathrm{C} 12-\mathrm{H} 12$ \\
\end{tabular}




\begin{tabular}{|c|c|c|c|}
\hline $\mathrm{C} 2-\mathrm{C} 1-\mathrm{C} 7$ & $122.8(4)$ & $\mathrm{C} 8-\mathrm{C} 13-\mathrm{H} 13 \mathrm{~A}$ & 109.5 \\
\hline $\mathrm{O} 1-\mathrm{C} 2-\mathrm{C} 3$ & $118.2(4)$ & $\mathrm{C} 8-\mathrm{C} 13-\mathrm{H} 13 \mathrm{~B}$ & 109.5 \\
\hline $\mathrm{O} 1-\mathrm{C} 2-\mathrm{C} 1$ & $122.7(4)$ & $\mathrm{H} 13 \mathrm{~A}-\mathrm{C} 13-\mathrm{H} 13 \mathrm{~B}$ & 109.5 \\
\hline $\mathrm{C} 3-\mathrm{C} 2-\mathrm{C} 1$ & $119.1(5)$ & $\mathrm{C} 8-\mathrm{C} 13-\mathrm{H} 13 \mathrm{C}$ & 109.5 \\
\hline $\mathrm{C} 4-\mathrm{C} 3-\mathrm{C} 2$ & $121.0(5)$ & $\mathrm{H} 13 \mathrm{~A}-\mathrm{C} 13-\mathrm{H} 13 \mathrm{C}$ & 109.5 \\
\hline $\mathrm{C} 4-\mathrm{C} 3-\mathrm{H} 3$ & 119.5 & $\mathrm{H} 13 \mathrm{~B}-\mathrm{C} 13-\mathrm{H} 13 \mathrm{C}$ & 109.5 \\
\hline $\mathrm{C} 2-\mathrm{C} 3-\mathrm{H} 3$ & 119.5 & $\mathrm{~N} 2-\mathrm{Cd} 1-\mathrm{N} 2^{\mathrm{i}}$ & $170.63(17)$ \\
\hline $\mathrm{C} 3-\mathrm{C} 4-\mathrm{C} 5$ & $120.4(4)$ & $\mathrm{N} 2-\mathrm{Cd} 1-\mathrm{O} 2$ & $69.83(11)$ \\
\hline $\mathrm{C} 3-\mathrm{C} 4-\mathrm{H} 4$ & 119.8 & $\mathrm{~N} 2 \mathrm{i}-\mathrm{Cd} 1-\mathrm{O} 2$ & $103.58(11)$ \\
\hline $\mathrm{C} 5-\mathrm{C} 4-\mathrm{H} 4$ & 119.8 & $\mathrm{~N} 2-\mathrm{Cd} 1-\mathrm{O} 2^{\mathrm{i}}$ & $103.58(11)$ \\
\hline $\mathrm{C} 6-\mathrm{C} 5-\mathrm{C} 4$ & $119.4(5)$ & $\mathrm{N} 2^{\mathrm{i}}-\mathrm{Cd} 1-\mathrm{O} 2^{\mathrm{i}}$ & $69.83(11)$ \\
\hline $\mathrm{C} 6-\mathrm{C} 5-\mathrm{H} 5$ & 120.3 & $\mathrm{O} 2-\mathrm{Cd} 1-\mathrm{O} 2^{\mathrm{i}}$ & $95.4(2)$ \\
\hline $\mathrm{C} 4-\mathrm{C} 5-\mathrm{H} 5$ & 120.3 & $\mathrm{~N} 2-\mathrm{Cd} 1-\mathrm{N} 3^{\mathrm{i}}$ & $117.27(11)$ \\
\hline $\mathrm{C} 5-\mathrm{C} 6-\mathrm{C} 1$ & $121.4(5)$ & $\mathrm{N} 22^{\mathrm{i}}-\mathrm{Cd} 1-\mathrm{N} 3^{\mathrm{i}}$ & $69.86(11)$ \\
\hline $\mathrm{C} 5-\mathrm{C} 6-\mathrm{H} 6$ & 119.3 & $\mathrm{O} 2-\mathrm{Cd} 1-\mathrm{N} 3^{\mathrm{i}}$ & $100.55(13)$ \\
\hline $\mathrm{C} 1-\mathrm{C} 6-\mathrm{H} 6$ & 119.3 & $\mathrm{O} 2^{\mathrm{i}}-\mathrm{Cd} 1-\mathrm{N} 3^{\mathrm{i}}$ & $139.07(10)$ \\
\hline $\mathrm{O} 2-\mathrm{C} 7-\mathrm{N} 1$ & $126.0(3)$ & $\mathrm{N} 2-\mathrm{Cd} 1-\mathrm{N} 3$ & $69.86(11)$ \\
\hline $\mathrm{O} 2-\mathrm{C} 7-\mathrm{C} 1$ & $119.0(4)$ & $\mathrm{N} 2{ }^{\mathrm{i}}-\mathrm{Cd} 1-\mathrm{N} 3$ & $117.27(11)$ \\
\hline $\mathrm{N} 1-\mathrm{C} 7-\mathrm{C} 1$ & $114.9(3)$ & $\mathrm{O} 2-\mathrm{Cd} 1-\mathrm{N} 3$ & $139.07(10)$ \\
\hline $\mathrm{N} 2-\mathrm{C} 8-\mathrm{C} 9$ & $115.0(4)$ & $\mathrm{O} 22^{\mathrm{i}}-\mathrm{Cd} 1-\mathrm{N} 3$ & $100.55(13)$ \\
\hline $\mathrm{N} 2-\mathrm{C} 8-\mathrm{C} 13$ & $122.8(5)$ & $\mathrm{N} 3{ }^{\mathrm{i}}-\mathrm{Cd} 1-\mathrm{N} 3$ & $91.59(16)$ \\
\hline $\mathrm{C} 9-\mathrm{C} 8-\mathrm{C} 13$ & $122.2(4)$ & $\mathrm{C} 7-\mathrm{N} 1-\mathrm{N} 2$ & $111.4(3)$ \\
\hline $\mathrm{N} 3-\mathrm{C} 9-\mathrm{C} 10$ & $119.0(4)$ & $\mathrm{C} 8-\mathrm{N} 2-\mathrm{N} 1$ & $120.2(3)$ \\
\hline $\mathrm{N} 3-\mathrm{C} 9-\mathrm{C} 8$ & $117.7(4)$ & $\mathrm{C} 8-\mathrm{N} 2-\mathrm{Cd} 1$ & $121.6(3)$ \\
\hline $\mathrm{C} 10-\mathrm{C} 9-\mathrm{C} 8$ & $123.2(4)$ & $\mathrm{N} 1-\mathrm{N} 2-\mathrm{Cd} 1$ & $117.5(2)$ \\
\hline $\mathrm{N} 4-\mathrm{C} 10-\mathrm{C} 9$ & $122.7(4)$ & $\mathrm{C} 12-\mathrm{N} 3-\mathrm{C} 9$ & $118.5(3)$ \\
\hline $\mathrm{N} 4-\mathrm{C} 10-\mathrm{H} 10$ & 118.6 & $\mathrm{C} 12-\mathrm{N} 3-\mathrm{Cd} 1$ & $126.5(3)$ \\
\hline $\mathrm{C} 9-\mathrm{C} 10-\mathrm{H} 10$ & 118.6 & $\mathrm{C} 9-\mathrm{N} 3-\mathrm{Cd} 1$ & $115.1(3)$ \\
\hline $\mathrm{N} 4-\mathrm{C} 11-\mathrm{C} 12$ & $122.1(4)$ & $\mathrm{C} 10-\mathrm{N} 4-\mathrm{C} 11$ & $116.5(4)$ \\
\hline $\mathrm{N} 4-\mathrm{C} 11-\mathrm{H} 11$ & 119.0 & $\mathrm{C} 2-\mathrm{O} 1-\mathrm{H} 1$ & $109(5)$ \\
\hline $\mathrm{C} 12-\mathrm{C} 11-\mathrm{H} 11$ & 119.0 & $\mathrm{C} 7-\mathrm{O} 2-\mathrm{Cd} 1$ & $114.1(3)$ \\
\hline $\mathrm{N} 3-\mathrm{C} 12-\mathrm{C} 11$ & $121.2(4)$ & & \\
\hline $\mathrm{C} 6-\mathrm{C} 1-\mathrm{C} 2-\mathrm{O} 1$ & $-179.3(4)$ & $\mathrm{C} 8-\mathrm{C} 9-\mathrm{C} 10-\mathrm{N} 4$ & $-179.3(4)$ \\
\hline $\mathrm{C} 7-\mathrm{C} 1-\mathrm{C} 2-\mathrm{O} 1$ & $4.8(6)$ & $\mathrm{N} 4-\mathrm{C} 11-\mathrm{C} 12-\mathrm{N} 3$ & $-0.4(6)$ \\
\hline $\mathrm{C} 6-\mathrm{C} 1-\mathrm{C} 2-\mathrm{C} 3$ & $0.8(6)$ & $\mathrm{O} 2-\mathrm{C} 7-\mathrm{N} 1-\mathrm{N} 2$ & $1.7(5)$ \\
\hline $\mathrm{C} 7-\mathrm{C} 1-\mathrm{C} 2-\mathrm{C} 3$ & $-175.2(4)$ & $\mathrm{C} 1-\mathrm{C} 7-\mathrm{N} 1-\mathrm{N} 2$ & $-179.1(3)$ \\
\hline $\mathrm{O} 1-\mathrm{C} 2-\mathrm{C} 3-\mathrm{C} 4$ & $-179.7(4)$ & $\mathrm{C} 9-\mathrm{C} 8-\mathrm{N} 2-\mathrm{N} 1$ & $-179.8(3)$ \\
\hline $\mathrm{C} 1-\mathrm{C} 2-\mathrm{C} 3-\mathrm{C} 4$ & $0.2(6)$ & $\mathrm{C} 13-\mathrm{C} 8-\mathrm{N} 2-\mathrm{N} 1$ & $1.4(6)$ \\
\hline $\mathrm{C} 2-\mathrm{C} 3-\mathrm{C} 4-\mathrm{C} 5$ & $-1.3(7)$ & $\mathrm{C} 9-\mathrm{C} 8-\mathrm{N} 2-\mathrm{Cd} 1$ & $10.1(5)$ \\
\hline $\mathrm{C} 3-\mathrm{C} 4-\mathrm{C} 5-\mathrm{C} 6$ & $1.3(6)$ & $\mathrm{C} 13-\mathrm{C} 8-\mathrm{N} 2-\mathrm{Cd} 1$ & $-168.8(3)$ \\
\hline $\mathrm{C} 4-\mathrm{C} 5-\mathrm{C} 6-\mathrm{C} 1$ & $-0.3(6)$ & $\mathrm{C} 7-\mathrm{N} 1-\mathrm{N} 2-\mathrm{C} 8$ & $-179.7(3)$ \\
\hline $\mathrm{C} 2-\mathrm{C} 1-\mathrm{C} 6-\mathrm{C} 5$ & $-0.7(6)$ & $\mathrm{C} 7-\mathrm{N} 1-\mathrm{N} 2-\mathrm{Cd} 1$ & $-9.2(4)$ \\
\hline $\mathrm{C} 7-\mathrm{C} 1-\mathrm{C} 6-\mathrm{C} 5$ & $175.4(4)$ & $\mathrm{C} 11-\mathrm{C} 12-\mathrm{N} 3-\mathrm{C} 9$ & $-1.0(6)$ \\
\hline $\mathrm{C} 6-\mathrm{C} 1-\mathrm{C} 7-\mathrm{O} 2$ & $-2.2(5)$ & $\mathrm{C} 11-\mathrm{C} 12-\mathrm{N} 3-\mathrm{Cd} 1$ & $179.4(3)$ \\
\hline $\mathrm{C} 2-\mathrm{C} 1-\mathrm{C} 7-\mathrm{O} 2$ & $173.7(4)$ & $\mathrm{C} 10-\mathrm{C} 9-\mathrm{N} 3-\mathrm{C} 12$ & $1.5(5)$ \\
\hline $\mathrm{C} 6-\mathrm{C} 1-\mathrm{C} 7-\mathrm{N} 1$ & $178.6(3)$ & $\mathrm{C} 8-\mathrm{C} 9-\mathrm{N} 3-\mathrm{C} 12$ & $-179.9(3)$ \\
\hline $\mathrm{C} 2-\mathrm{C} 1-\mathrm{C} 7-\mathrm{N} 1$ & $-5.5(5)$ & $\mathrm{C} 10-\mathrm{C} 9-\mathrm{N} 3-\mathrm{Cd} 1$ & $-178.8(3)$ \\
\hline
\end{tabular}




$\begin{array}{llll}\mathrm{N} 2-\mathrm{C} 8-\mathrm{C} 9-\mathrm{N} 3 & -6.2(5) & \mathrm{C} 8-\mathrm{C} 9-\mathrm{N} 3-\mathrm{Cd} 1 & -0.2(4) \\ \mathrm{C} 13-\mathrm{C} 8-\mathrm{C} 9-\mathrm{N} 3 & 172.6(4) & \mathrm{C} 9-\mathrm{C} 10-\mathrm{N} 4-\mathrm{C} 11 & -0.6(6) \\ \mathrm{N} 2-\mathrm{C} 8-\mathrm{C} 9-\mathrm{C} 10 & 172.3(4) & \mathrm{C} 12-\mathrm{C} 11-\mathrm{N} 4-\mathrm{C} 10 & 1.2(6) \\ \mathrm{C} 13-\mathrm{C} 8-\mathrm{C} 9-\mathrm{C} 10 & -8.8(6) & \mathrm{N} 1-\mathrm{C} 7-\mathrm{O} 2-\mathrm{Cd} 1 & 6.4(5) \\ \mathrm{N} 3-\mathrm{C} 9-\mathrm{C} 10-\mathrm{N} 4 & -0.8(6) & \mathrm{C} 1-\mathrm{C} 7-\mathrm{O} 2-\mathrm{Cd} 1 & -172.7(3)\end{array}$

Symmetry code: (i) $-x+1,-y+1, z$.

Hydrogen-bond geometry $\left(A,{ }^{\circ}\right)$

$C g 1$ and $C g 2$ are the centroids of the $\mathrm{C} 1-\mathrm{C} 6$ and N3-N4/C9-C12 rings, respectively.

\begin{tabular}{lllll}
\hline$D-\mathrm{H} \cdots A$ & $D-\mathrm{H}$ & $\mathrm{H} \cdots A$ & $D \cdots A$ & $D-\mathrm{H} \cdots A$ \\
\hline $\mathrm{C} 4-\mathrm{H} 4 \cdots \mathrm{N} 4^{\mathrm{ii}}$ & 0.95 & 2.47 & $3.349(6)$ & 154 \\
$\mathrm{C} 10-\mathrm{H} 10 \cdots \mathrm{O} 2^{\mathrm{iii}}$ & 0.95 & 2.55 & $3.283(5)$ & 134 \\
$\mathrm{C} 12-\mathrm{H} 12 \cdots 1^{\mathrm{iv}}$ & 0.95 & 2.49 & $3.439(5)$ & 174 \\
$\mathrm{O} 1-\mathrm{H} 1 \cdots \mathrm{N} 1$ & $0.90(8)$ & $1.76(8)$ & $2.557(4)$ & $146(7)$ \\
$\mathrm{C} 13-\mathrm{H} 13 A \cdots C g 2^{\mathrm{v}}$ & 0.98 & 2.86 & $3.740(6)$ & 149 \\
$\mathrm{C} 13-\mathrm{H} 13 B \cdots C g 1^{\mathrm{vi}}$ & 0.98 & 2.71 & $3.592(6)$ & 150
\end{tabular}

Symmetry codes: (ii) $-x+3 / 2, y+1 / 2, z+1$; (iii) $x+1 / 2,-y+1, z-1 / 2$; (iv) $x-1 / 2,-y+1, z-1 / 2$; (v) $-x+3 / 2, y, z+1 / 2$; (vi) $-x+3 / 2, y, z-1 / 2$. 